\title{
Nitrate Removal Performance of Denitrifying Woodchip Bioreactors in Tropical Climates
}

\author{
Fabio Manca ${ }^{1, *}$, Carla Wegscheidl ${ }^{2}\left(\mathbb{D}\right.$, Rhianna Robinson ${ }^{3}$, Suzette Argent ${ }^{4}$, Christopher Algar ${ }^{5}(\mathbb{D}$, \\ Daniele De Rosa ${ }^{1}{ }^{\mathbb{D}}$, Matthew Griffiths ${ }^{6}$, Fiona George ${ }^{7}$, David Rowlings ${ }^{1}$, Louis Schipper ${ }^{8}$ and Peter Grace ${ }^{1}$
}

check for updates

Citation: Manca, F.; Wegscheidl, C.; Robinson, R.; Argent, S.; Algar, C.; De Rosa, D.; Griffiths, M.; George, F.; Rowlings, D.; Schipper, L.; et al. Nitrate Removal Performance of Denitrifying Woodchip Bioreactors in Tropical Climates. Water 2021, 13, 3608. https://doi.org/10.3390/ w13243608

Academic Editors: Jongkwon Im, Xuwang Zhang, Laura Bulgariu, Christos S. Akratos and Francisco Osorio

Received: 8 November 2021 Accepted: 9 December 2021 Published: 15 December 2021

Publisher's Note: MDPI stays neutral with regard to jurisdictional claims in published maps and institutional affiliations.

Copyright: (c) 2021 by the authors. Licensee MDPI, Basel, Switzerland. This article is an open access article distributed under the terms and conditions of the Creative Commons Attribution (CC BY) license (https:// creativecommons.org/licenses/by/ $4.0 /)$.
1 Centre for Agriculture and the Bioeconomy, Queensland University of Technology, 2 George Street, Brisbane 4000, Australia; agr.derosadaniele@gmail.com (D.D.R.); d.rowlings@qut.edu.au (D.R.); pr.grace@qut.edu.au (P.G.)

2 Queensland Department of Agriculture and Fisheries, 9-15 Langton Street, Garbutt 4814, Australia; carla.wegscheidl@daf.qld.gov.au

3 Queensland Department of Agriculture and Fisheries, 47 Mayers Road, Nambour 4560, Australia; rhianna.robinson@daf.qld.gov.au

4 Berries Australia, P.O. Box 578, Archerfield 4108, Australia; s.argent@live.com

5 Copper Resources Australia, 45 Grenfell Street, Adelaide 5000, Australia; chris@thealgars.com

6 Department of Environment and Science, Queensland Government, Brisbane 4000, Australia; matthew.griffiths@des.qld.gov.au

7 Terrain NRM, 63 Anderson Street, Manunda 4870, Australia; fiona.george@terrain.org.au

8 School of Science, University of Waikato, Hamilton 3240, New Zealand; louis.schipper@waikato.ac.nz

* Correspondence: f.manca@qut.edu.au

Abstract: In Australia, declining water quality in the Great Barrier Reef (GBR) is a threat to its marine ecosystems and nitrate $\left(\mathrm{NO}_{3}{ }^{-}\right)$from sugar cane-dominated agricultural areas in the coastal catchments of North Queensland is a key pollutant of concern. Woodchip bioreactors have been identified as a potential low-cost remediation technology to reduce the $\mathrm{NO}_{3}{ }^{-}$runoff from sugar cane farms. This study aimed to trial different designs of bioreactors (denitrification walls and beds) to quantify their $\mathrm{NO}_{3}{ }^{-}$removal performance in the distinct tropical climates and hydrological regimes that characterize sugarcane farms in North Queensland. One denitrification wall and two denitrification beds were installed to treat groundwater and subsurface tile-drainage water in wet tropics catchments, where sugar cane farming relies only on rainfall for crop growth. Two denitrification beds were installed in the dry tropics to assess their performance in treating irrigation tailwater from sugarcane. All trialled bioreactors were effective at removing $\mathrm{NO}_{3}{ }^{-}$, with the beds exhibiting a higher $\mathrm{NO}_{3}{ }^{-}$removal rate (NRR, from 2.5 to $7.1 \mathrm{~g} \mathrm{~N} \mathrm{~m}^{-3} \mathrm{~d}^{-1}$ ) compared to the wall $\left(0.15 \mathrm{~g} \mathrm{~N} \mathrm{~m}^{-3} \mathrm{~d}^{-1}\right)$. The NRR depended on the influent $\mathrm{NO}_{3}{ }^{-}$concentration, as low influent concentrations triggered $\mathrm{NO}_{3}{ }^{-}$limitation. The highest NRR was observed in a bed installed in the dry tropics, with relatively high and consistent $\mathrm{NO}_{3}{ }^{-}$influent concentrations due to the use of groundwater, with elevated $\mathrm{NO}_{3}{ }^{-}$, for irrigation. This study demonstrates that bioreactors can be a useful edge-of-field technology for reducing $\mathrm{NO}_{3}{ }^{-}$in runoff to the GBR, when sited and designed to maximise $\mathrm{NO}_{3}{ }^{-}$removal performance.

Keywords: denitrification; woodchip bioreactor; denitrification bed; denitrification wall; nitrogen; nitrate; sugarcane; tile-drainage; tropical climate; Australia

\section{Introduction}

In agricultural systems, nitrogen $(\mathrm{N})$ applied in excess to plant requirements can be lost to the environment in the form of nitrate $\left(\mathrm{NO}_{3}{ }^{-}\right)$and can leach into shallow groundwater and enter surface waters through concentrated or diffuse discharges [1]. Nitrate is a reactive form of $\mathrm{N}$ (i.e., directly or indirectly supports growth) and can trigger environmental issues such as eutrophication, algae blooms, and fish mortality [2,3]. 
In the Great Barrier Reef in northern Australia, poor water quality associated with catchment runoff threatens the condition of important marine ecosystems [4]. Sugarcane production systems, common in the coastal floodplains adjacent to the GBR [5], have been identified as a main source of reactive $\mathrm{N}$ contributing to the deterioration of the water quality in the GBR [6]. Nitrogen runoff is related to outbreaks of the Crown of Thorns starfish [7], a corallivorous organism which has contributed to a 50\% decline in coral cover over the last three decades [8]. The Australian and Queensland Governments have set targets for pollutant reductions and have invested in programs to improve agricultural management practices. The water quality targets will not be met at the current rate of management practice adoption and additional water quality improvement actions are needed [4].

Denitrifying bioreactors are a passive, low-cost edge-of-field technology developed to intercept and treat $\mathrm{NO}_{3}{ }^{-}$-enriched water in agricultural systems before entering receiving waterways. Bioreactors are containers filled with a carbon source, often woodchip, to enhance heterotrophic denitrification [9], a microbially-catalysed respiration process that progressively reduces $\mathrm{NO}_{3}{ }^{-}$to harmless dinitrogen gas [10]. The heterotrophic denitrification rate is controlled by the concentrations of oxygen, $\mathrm{NO}_{3}{ }^{-}$and carbon [2]. Hence, bioreactors are designed to maximise this natural process by creating a saturated, low oxygen environment full of a degradable carbon source to promote the removal of $\mathrm{NO}_{3}{ }^{-}$. Different designs of bioreactors (i.e., denitrification walls and denitrification beds) have been developed and adapted to different agricultural settings [1], with the benefit of being installed at the edge-of-field to minimally impact agricultural practices and productive land [11]. Denitrification walls (hereafter "walls") are installed in sandy aquifers perpendicular to the groundwater flow direction, to treat shallow groundwater, whereas denitrification beds (hereafter "beds") treat either subsurface water that has leached beyond the rootzone (i.e., tile-drainage water) or surface runoff (i.e., drainage water, irrigation tailwater) [12]. Walls and beds have both been successful at removing $\mathrm{NO}_{3}{ }^{-}$in a range of agricultural settings, with nitrate removal rates ranging from 0.01 to $3.6 \mathrm{~g} \mathrm{~N} \mathrm{~m}^{-3} \mathrm{~d}^{-1}$ and from 2 to $22 \mathrm{~g} \mathrm{~N} \mathrm{~m}^{-3} \mathrm{~d}^{-1}$ respectively [1].

Hydrology and temperature are important drivers for $\mathrm{NO}_{3}{ }^{-}$removal in a field bioreactor. Rainfall generates surface runoff and vertical movement of subsurface water to groundwater, and the frequency and intensity of rainfall determines irrigation requirements in agricultural systems. Both rainfall and irrigation determine the transport of $\mathrm{NO}_{3}{ }^{-}$ in surface runoff and its leaching to groundwater, and consequently regulate $\mathrm{NO}_{3}{ }^{-}$influent variability in bioreactors. The influent $\mathrm{NO}_{3}{ }^{-}$concentration affects the $\mathrm{NO}_{3}{ }^{-}$removal performance of bioreactors [13]. When $\mathrm{NO}_{3}{ }^{-}$is not limiting (i.e., when the effluent $\mathrm{NO}_{3}{ }^{-}$ is $>0.5 \mathrm{mg} \mathrm{N} \mathrm{L}^{-1}$ [14]), $\mathrm{NO}_{3}{ }^{-}$removal rates are higher at higher influent $\mathrm{NO}_{3}{ }^{-}$concentrations $[14,15]$. Under $\mathrm{NO}_{3}{ }^{-}$limiting conditions, all the available $\mathrm{NO}_{3}{ }^{-}$can be consumed by microbes with significantly lower values of removal compared to non- $\mathrm{NO}_{3}{ }^{-}$-limiting conditions [14].

Temperature accelerates microbial metabolism and, consequently, $\mathrm{NO}_{3}{ }^{-}$removal [16]. Laboratory column experiments have observed the dependence of $\mathrm{NO}_{3}{ }^{-}$removal on temperature, with increased $\mathrm{NO}_{3}{ }^{-}$removal at higher temperatures [15,17], and Hassanpour, et al. [18] observed large increases of $\mathrm{NO}_{3}{ }^{-}$removal at temperatures $>16^{\circ} \mathrm{C}$, likely related to a seasonal change in the bacterial community.

Most of the world's bioreactors have been designed as beds for treating subsurface water collected in tile-drains under corn-soybean rotational cropping systems in the humid continental climate of the U.S. mid-west, to reduce the size of the hypoxic zone in the Gulf of Mexico [19]. Beds have been trialled in Illinois [20,21], Iowa [22,23], Minnesota [24,25], and South Dakota [26] as well as in the east coast state of New York [18]. Bioreactors have been installed under similar cropping systems in the more temperate humid subtropical climate of Maryland and Virginia [27,28], or adapted to the treatment of surface water in agricultural ditches and groundwater in Maryland [29]. Bioreactors have also been trialled in the temperate oceanic climate of New Zealand, where they have been applied to treat 
shallow groundwater or tile-drainage subsurface water on grazed dairy farms [30,31], or to treat effluent from glasshouses [32]. $\mathrm{A} \mathrm{NO}_{3}{ }^{-}$plume in shallow groundwater from a cattle feedlot has also been successfully treated in Western Australia [33] under a Mediterranean climate. In 2017, two denitrification walls filled with contrasting woodchip (softwood vs hardwood) were installed on a pineapple farm in southeast Queensland, an area subject to a humid subtropical climate, and proved effective at removing $\mathrm{NO}_{3}{ }^{-}$[34].

In 2017, the Queensland Reef Water Quality Program funded the first trials of bioreactors in the GBR catchments to investigate the effectiveness of bioreactors in reducing $\mathrm{NO}_{3}{ }^{-}$from sugarcane production systems in tropical Australian climates. The aim was to identify the potential role of woodchip bioreactors in improving water quality entering the GBR lagoon and to use the results to develop guidelines for their future installation [35,36]. Consequently, trials were carried out in sugarcane production systems of North Queensland, located in the wet tropics and dry tropics regions and subject to distinct hydrological regimes. The wet tropics region is subject to a tropical rainforest climate, and irrigation is generally not required for sugarcane production. Rainfall triggers leaching of $\mathrm{NO}_{3}{ }^{-}$to groundwater and loss of $\mathrm{NO}_{3}{ }^{-}$via surface runoff from sugarcane farms [37-39]. Due to the magnitude of the rainfall in the region, subsurface tile-drainage systems have been implemented in some areas to remove excess water from the sugarcane root zone.

The dry tropics region is subject to a tropical savanna climate, with a short summer rainy season and extended dry season. Irrigation is required for most of the year in these sugarcane production systems. Irrigation water is sourced either from groundwater or surface water, depending on aquifer yields, groundwater quality and proximity to rivers or channels [40]. Irrigation promotes $\mathrm{NO}_{3}{ }^{-}$leaching to groundwater [41,42] and large volumes of $\mathrm{NO}_{3}{ }^{-}$-enriched tailwater, which can account for 10 to $70 \%$ of the total water applied to a field [43].

Bioreactors have been shown to be effective at removing $\mathrm{NO}_{3}{ }^{-}$in a range of agricultural settings in temperate and some sub-tropical climates, yet their efficacy in tropical Australian climates with their high temperatures and distinct hydrology has not been quantified.

The aim of this study was to quantify the $\mathrm{NO}_{3}{ }^{-}$removal performance of bioreactors installed on rainfed and irrigated sugarcane production systems under tropical climates, using different designs to provide technical and practical guidance for their deployment in GBR catchments.

\section{Materials and Methods}

\subsection{Wet Tropics Bioreactors}

\subsubsection{Study Area}

Three bioreactors were installed in the Johnstone and Tully catchments, located in North Queensland, $\sim 110 \mathrm{~km}$ southeast of Cairns (Figure 1). They are part of the wet tropics region of Queensland and are subject to a tropical rainforest climate according to the Köppen climate classification [44]. The wet monsoonal season occurs from November to April, inclusive [45], with an average yearly rainfall of 2763 and $3152 \mathrm{~mm}$ in the Tully and Johnstone catchment, respectively [46,47]. The highest average monthly temperatures are observed during the summer month of December and January, with maximum values of $33{ }^{\circ} \mathrm{C}$, whereas the lowest average monthly temperatures are observed in July, with minimum values of $16{ }^{\circ} \mathrm{C}$ [48]. One wall (BR1) was installed to treat shallow groundwater, whereas two beds (BR2 and BR3) were installed to treat subsurface tile-drainage water. 


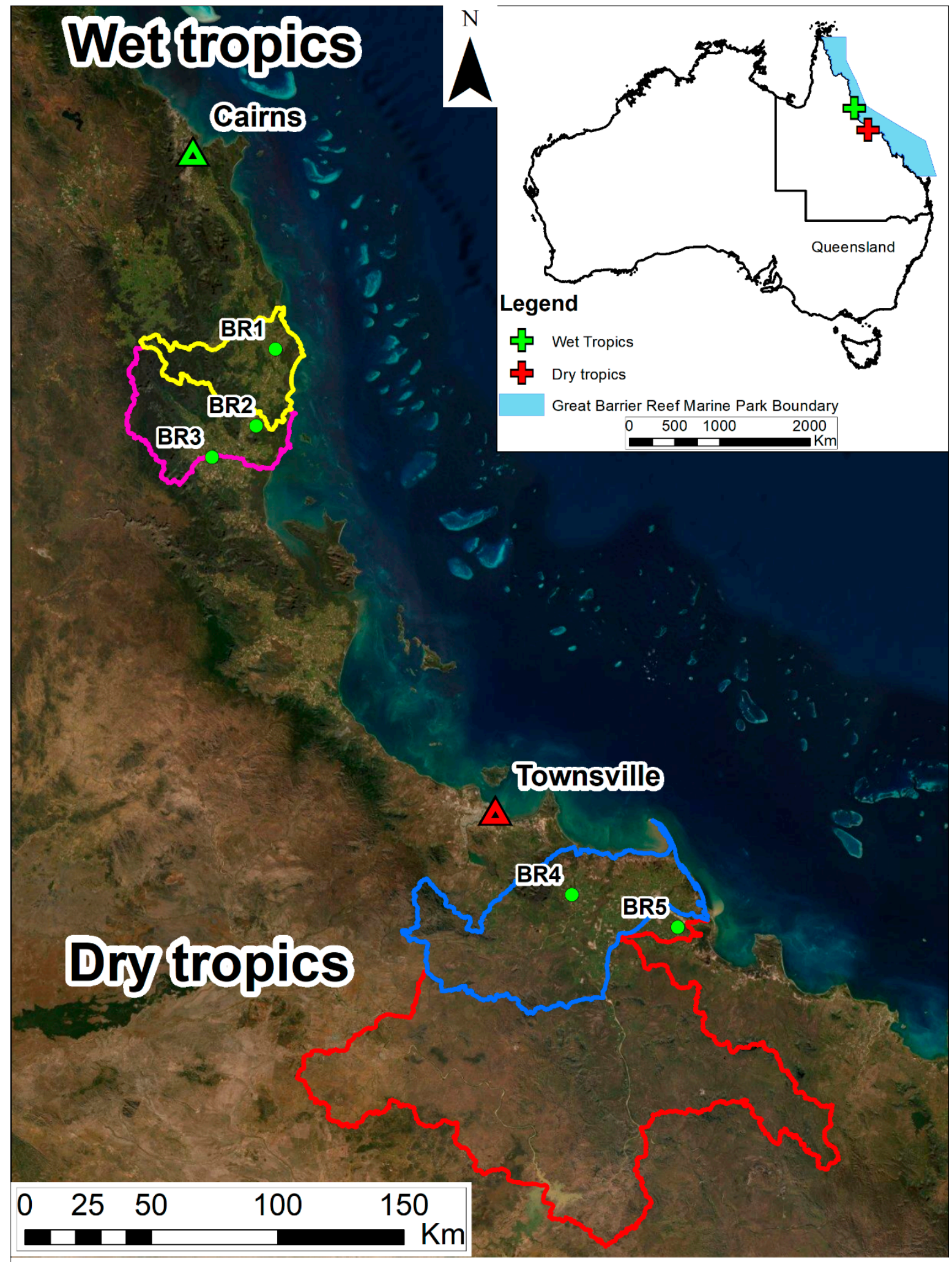

\section{Legend}

Bioreactors $\square$ Johnstone catchment $\square$ Tully catchment $\square$ Haughton catchment $\square$ Lower Burdekin catchment

Figure 1. Location of the bioreactors installed on sugar cane farms in the catchments of the wet tropics region (Johnstone and Tully) and dry tropics region (Haughton and Lower Burdekin) of North Queensland, Australia, adjacent to the Great Barrier Reef Marine Park. 


\subsubsection{BR1}

The denitrification wall BR1 was installed at the edge of a sugarcane paddock in August 2018, in a 7.0 ha drainage catchment area. It treated rainfall-recharged shallow groundwater flowing across a sandy-loam aquifer underlain by a shallow clay layer $(\sim 2 \mathrm{~m}$ below the surface) in the Johnstone catchment (Table 1). The wall was $30.0 \mathrm{~m}$ long, $1.5 \mathrm{~m}$ deep, and had a variable width ranging from 0.6 (at the bottom) to $2.1 \mathrm{~m}$ (at the top), as it was constructed with a " $\mathrm{V}$ " shaped cross section to prevent soil collapse due to the sandy-loam nature of the aquifer (Figure S1). The wall was filled with a total volume of $60.8 \mathrm{~m}^{3}$ of hardwood woodchip. Three monitoring transects were installed using $100 \mathrm{~mm}$ diameter PVC piezometers. The installations were in parallel to the maximum length of the wall to collect replicate water samples $(\mathrm{n}=3)$ from up-gradient (influent, $\mathrm{T} 1)$, from the wall (woodchip, T2), and from down-gradient (effluent, T3). The groundwater levels and water quality of the wall were monitored fortnightly during the wet seasons from January 2019 until March 2021.

\subsubsection{BR2}

The off-line bed BR2 was installed in October 2019 in a 9.5 ha sugarcane drainage catchment area to treat tile-drainage subsurface water in the Tully catchment (Table 1). The bed was $10.0 \mathrm{~m}$ long, $1.0 \mathrm{~m}$ deep, and $1.5 \mathrm{~m}$ wide (Figure S2) and filled with a total volume of $15.0 \mathrm{~m}^{3}$ of softwood woodchip. The bed was connected to a tile-drain using a $100 \mathrm{~mm}$ diameter PVC pipe to divert all the subsurface water flow into the bioreactor.

Inlet and outlet control structures were constructed upslope and downslope of the bed to collect influent and effluent water samples, respectively. The woodchip within the bioreactor was constantly saturated due to the outlet pipe being installed at the top of bed. The water quality of the bed was monitored weekly during the wet seasons from January 2020 until March 2021.

\subsubsection{BR3}

The off-line bed BR3 was installed in October 2019 in a 2.6 ha sugarcane drainage catchment area to treat tile-drainage subsurface water in the Tully catchment (Table 1). The bed was $10.0 \mathrm{~m}$ long, $1.0 \mathrm{~m}$ deep, and $1.5 \mathrm{~m}$ wide (Figure S3) and filled with a total volume of $15.8 \mathrm{~m}^{3}$ of softwood woodchip.

The bed was connected to a tile-drain using a $100 \mathrm{~mm}$ diameter PVC pipe to divert all the subsurface water flow into the bioreactor. Influent samples were collected directly from the effluent of the tile-drain. An outlet control structure was installed downslope of the bed to collect effluent water samples. The woodchip within the bioreactor was kept constantly saturated due to the outlet pipe being installed at the top of bed. The water quality of the bed was monitored weekly during the wet seasons from January 2020 until March 2021. 


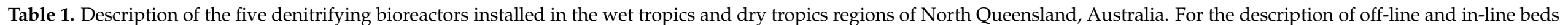
please refer to Wegscheidl, et al. [35].

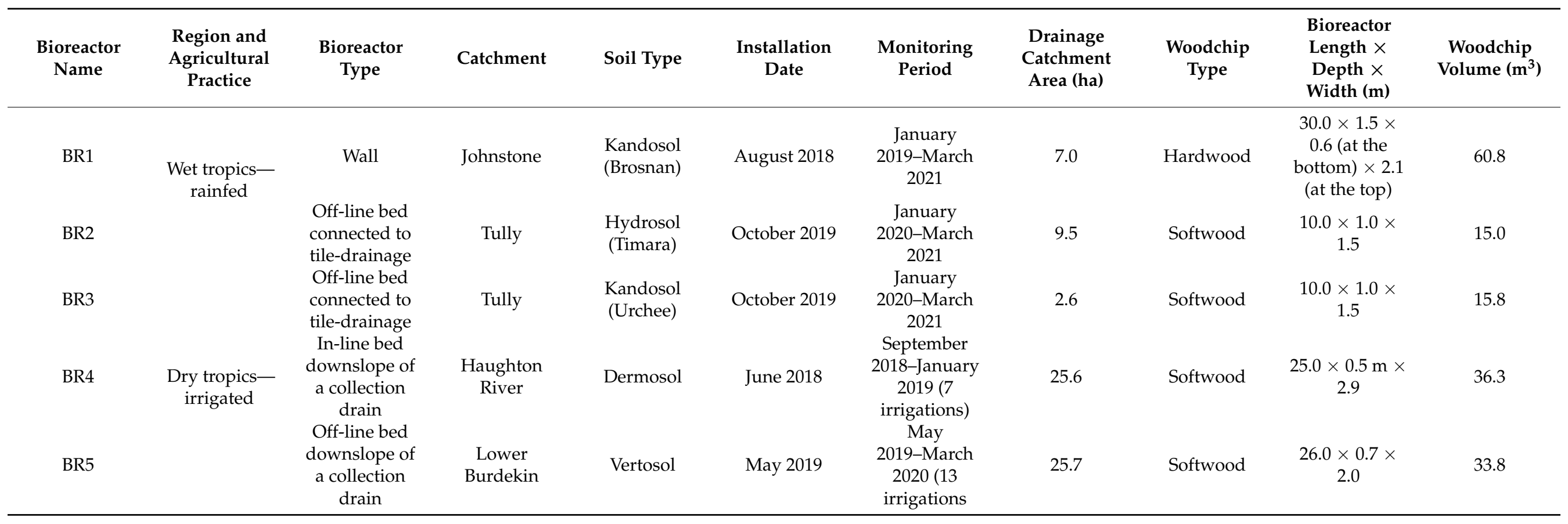




\subsection{Dry Tropics Bioreactors}

\subsubsection{Study Area}

Two bioreactors were installed in the Haughton and Lower Burdekin catchments, located in North Queensland, $50 \mathrm{~km}$ southeast of Townsville (Figure 1). They are part of the dry tropics region of Queensland and are subject to a tropical savanna climate according to the Köppen climate classification [44]. The wet monsoonal season occurs from November to April inclusive [49], and provides an average yearly rainfall of 953 and $633 \mathrm{~mm}$ in the Haughton and Lower Burdekin catchments, respectively [50,51]. The highest average monthly temperatures are observed during the summer months of December and January, with maximum values of $32{ }^{\circ} \mathrm{C}$, whereas the lowest average monthly temperatures are observed in July, with minimum values of $11.6^{\circ} \mathrm{C}$ [52].

In the Haughton and Lower Burdekin catchments, furrow irrigation is required for the majority of the year and applied using gated pipes located at the top end of the paddock divided into irrigation sets, with sets irrigated progressively. Irrigation events have variable frequency and duration, depending on the rainfall occurrence, soil type, paddock size, crop growth stage [53], and the presence of crop residues. High irrigation flow rates are usually applied to permit a fast movement of water into the furrows and reduce deep drainage losses [53]. Irrigation tailwater is normally collected in drains located at the bottom end of the paddock and discharged either into recycling pits to be reused, or into channels.

The two beds (BR4 and BR5) were installed to treat surface irrigation tailwater. Given the size of the beds compared to the volume of the irrigation tailwater, only a small proportion of the water was captured and treated in the beds.

\subsubsection{BR4}

The in-line bed BR4 was installed in June 2018 downslope of a 25.6 ha sugarcane paddock to treat irrigation tailwater in the Haughton River catchment (Table 1). Irrigation water was sourced from a river and a recycling pit. Irrigations lasted from 25 to $117 \mathrm{~h}$, with the longer events occurring in the presence of crop residues, when the crop was at an early growth stage. The bed was $25.0 \mathrm{~m}$ long, $0.5 \mathrm{~m}$ deep, and $2.9 \mathrm{~m}$ wide (Figure S4) and filled with a total volume of $36.3 \mathrm{~m}^{3}$ of softwood woodchip. The bed was installed in an irrigation drain to receive a proportion of the diverted irrigation tailwater. Excess surface water flowed over the top of the bed into a recycling pit. A sediment trap, comprising a series of hardwood sleeper baffles, was installed prior to the inlet structure to capture sediment transported in the irrigation tailwater. The inlet structure was constructed using rows of rock-filled gabion baskets wrapped in geo-fabric filled with gravel, for an overall inlet volume of $4.5 \mathrm{~m}^{3}$. A bentonite-impregnated liner was used to line the woodchip. The outlet structure was constructed using four $50 \mathrm{~mm}$ diameter PVC pipes connected perpendicular to a pre-drilled $200 \mathrm{~mm}$ diameter PVC pipe wrapped in geo-fabric, passing through the gabion baskets. The outlet pipes were installed at the base of the bed to permit a complete drainage of the woodchip. Piezometers were installed to monitor the water quality using $100 \mathrm{~mm}$ diameter PVC pipes slotted at the base. One piezometer was installed within the gravel of the inlet structure. Three additional piezometers were installed in the woodchip at intervals from the inlet piezometer. The water quality of the bed was monitored four times a day (every $6 \mathrm{~h}$ ) during seven irrigation events from September 2018 until January 2019.

\subsubsection{BR5}

The off-line bed BR5 was constructed in May 2019 downslope of a 25.7 ha sugarcane paddock to treat irrigation tailwater in the Lower Burdekin catchment (Table 1).

Irrigation water was sourced from three groundwater bores with a background $\mathrm{NO}_{3}{ }^{-}$ concentration of 2-3 $\mathrm{mg} \mathrm{N} \mathrm{L}^{-1}$ and mixed with channel water when required. Irrigations lasted from 35 to $66 \mathrm{~h}$. The bed was $26.0 \mathrm{~m}$ long, $0.7 \mathrm{~m}$ deep, and $2.0 \mathrm{~m}$ wide (Figure S5) and filled with a total volume of $33.8 \mathrm{~m}^{3}$ of softwood woodchip. The bioreactor was installed next to an irrigation channel located in a low-lying uncropped area at $2.8 \mathrm{~m}$ below the 
surrounding sugarcane paddocks. The inlet structure received a proportion of the irrigation tailwater from an underground bypass pipe. Excess water flowed into the adjacent lowlying uncropped area. The inlet structure was constructed using a trench filled with gravel and gabion baskets for an overall volume of approximately $4.6 \mathrm{~m}^{3}$. A plastic liner was used to wrap the woodchip. The outlet structure was constructed using four separate drilled 100 $\mathrm{mm}$ diameter PVC pipes wrapped in geo-fabric, connected with reduction sockets to four $50 \mathrm{~mm}$ PVC diameter pipes. The outlet pipes were installed at the base of the bed to permit the complete drainage of the woodchip. Piezometers were installed using $100 \mathrm{~mm}$ diameter PVC pipes slotted at the base to monitor the water quality. One piezometer was installed within the gravel of the inlet structure. Three additional piezometers were installed in the woodchip at intervals from the inlet piezometer. The water quality of the bed was monitored four times a day (every $6 \mathrm{~h}$ ) during thirteen irrigation events from May 2019 until March 2020.

\subsection{Water Sampling}

Different research groups monitored the wet tropics and the dry tropics bioreactors. Different methods were used to collect and analyse the water samples. The sampling and analytical methods are summarized in the following paragraphs.

\subsubsection{Wet Tropics}

Water sampling was performed manually using an electric pump and samples were collected in a $50 \mathrm{~mL}$ PET bottle. After collection, samples were transported to Cairns CRC Laboratories and filtered $(0.45 \mu \mathrm{m})$ prior to analysis. The quantification of total oxidized $\mathrm{N}$, total ammonia $\mathrm{N}$ and nitrite was performed colorimetrically (Aquakem 200 Photometric Analyzer, Thermo-Fisher-Scientific, Waltham, MA, USA). The amount of $\mathrm{NO}_{3}{ }^{-}$was calculated as the difference between total oxidized $\mathrm{N}$, nitrite and total ammonia $\mathrm{N}$. The amount of ammonium $\left(\mathrm{NH}_{4}{ }^{+}\right)$was calculated from the total ammonia $\mathrm{N}$ according to ANZECC and ARMCANZ [54].

At each sampling event, values of $\mathrm{pH}$, water temperature, and oxygen saturation (\%) were measured in the field using a portable instrument (ProDSS, YSI, Yellow Springs, OH, USA). Oxygen saturation was converted to dissolved oxygen (DO) concentration using the equation of Weiss [55], valid between 2 and $40^{\circ} \mathrm{C}$, at salinity $=0$. The temperature of the water was also monitored hourly using pressure transducers (HOBO U20L-04, Onset, Bourne, MA, USA) installed within the wall BR1 (T2) and in the outlet structures of the beds BR2 and BR3.

\subsubsection{Dry Tropics}

High frequency water sampling was performed four times a day (every $6 \mathrm{~h}$ ), collecting samples from the inlet and the outlet of both beds. Two water sampling events were conducted manually during the day using either an electric or hand-operated pump, and two additional water sampling events occurred at night-time using automated samplers (ISCO 3700, Teledyne ISCO, Lincoln, NE, USA). The monitoring strategy of four samples a day was implemented to maximize the likelihood of capturing potential short-lived $\mathrm{NO}_{3}{ }^{-}$ pulses and quantify the $\mathrm{NO}_{3}{ }^{-}$variability at the inlet.

Sampled water was collected in two $200 \mathrm{~mL}$ PET bottles. One of the bottles was acidified with sulphuric acid to $\mathrm{pH}<2$ to prevent ammonia volatilization. Samples were frozen after collection and cold-freighted to Brisbane Queensland University of Technology laboratories for analysis. Non-acidified samples were filtered $(0.45 \mu \mathrm{m})$ prior to being analysed for $\mathrm{NO}_{3}{ }^{-}$. Additionally, acidified samples were filtered and analysed for $\mathrm{NH}_{4}{ }^{+}$. Analysis of $\mathrm{NO}_{3}{ }^{-}$and $\mathrm{NH}_{4}{ }^{+}$was performed photometrically (Gallery ${ }^{\mathrm{TM}}$ Discrete Analyser, Thermo-Fisher Scientific, Waltham, MA, USA). At each sampling event, the values of $\mathrm{pH}$, water temperature, and DO were measured in the field using a portable instrument (WP91, TPS, Brendale, QLD, Australia). The temperature of the water was also monitored hourly 
using pressure transducers (HOBO U20L-04, Onset, Bourne, MA, USA) installed in the outlet piezometers of the beds BR4 and BR5.

\subsubsection{Comparability of Analytical Results}

After the calibration of the analytical instruments, each laboratory performed a quality control program on the chemical analysis results. The quality control program included analyses of field blanks, field duplicates, laboratory blanks, and laboratory control standards. Given the similarity of the quality control program, the chemical analysis results of the wet tropics and the dry tropics bioreactors were considered satisfactory and comparable.

\subsection{Nitrate Removal Calculation}

The $\mathrm{NO}_{3}{ }^{-}$removal performance of the wall and the beds was calculated in terms of the $\mathrm{NO}_{3}{ }^{-}$removal rate (NRR, $\mathrm{g} \mathrm{N} \mathrm{m}^{-3} \mathrm{~d}^{-1}$ ), a standardised metric for comparing removal across different bioreactors, taking into account flow rate and the saturated woodchip volume.

The NRR of the wall BR1 was calculated similarly to Schipper and Vojvodić-Vuković [56]:

$$
\mathrm{NRR}=\frac{\left(\Delta \mathrm{NO}_{3}^{-}\right) \times v \times A \times \varphi_{c}}{V_{\text {sat }}}
$$

where $\Delta \mathrm{NO}_{3}{ }^{-}\left(\mathrm{g} \mathrm{N} \mathrm{m}^{-3}\right)$ is the difference between the average concentrations of the water samples collected from the piezometers $(\mathrm{n}=3)$ of T1 and T2 at each sampling event, $v$ $\left(\mathrm{m} \mathrm{d}^{-1}\right)$ is the groundwater velocity, $A\left(\mathrm{~m}^{2}\right)$ is the saturated woodchip section transmitting groundwater measured at the time of sampling using the pressure transducer, $\varphi_{c}\left(\mathrm{~m}^{3} \mathrm{~m}^{-3}\right)$ is the macro porosity of the woodchip, and $V_{\text {sat }}\left(\mathrm{m}^{3}\right)$ is the saturated woodchip volume at the time of sampling. A value of $\varphi_{c}=0.76$ was used, similar to the value measured for hardwood (Eucalyptus) by Cameron and Schipper [57]. Occasionally, $\mathrm{NO}_{3}{ }^{-}$was detected in T2 and if:

$$
\left(\mathrm{NO}_{3 \mathrm{~T} 2}^{-}\right)>\frac{\left(\mathrm{NO}_{3 \mathrm{~T} 1}^{-}\right)}{2}
$$

The $\Delta \mathrm{NO}_{3}{ }^{-}$was calculated assuming first-order removal kinetics, which can be observed at low $\mathrm{NO}_{3}{ }^{-}$concentrations (3.0 $\left.\mathrm{mg} \mathrm{N} \mathrm{L}^{-1}\right)$ [58] as:

$$
\left(\Delta \mathrm{NO}_{3}^{-}\right)=\left[\left(\mathrm{NO}_{3 \mathrm{~T} 1}^{-}\right)-\left(\mathrm{NO}_{3 \mathrm{~T} 2}^{-}\right)\right] \times 2
$$

The groundwater velocity $\left(v, \mathrm{~m} \mathrm{~d}^{-1}\right)$ in the aquifer was calculated using Darcy's law [59]:

$$
v=i \frac{K}{\varphi_{a}}
$$

where $K\left(\mathrm{~m} \mathrm{~d}^{-1}\right)$ is the hydraulic conductivity of the aquifer, $i\left(\mathrm{~m} \mathrm{~m}^{-1}\right)$ is the hydraulic gradient, and $\varphi_{a}\left(\mathrm{~m}^{3} \mathrm{~m}^{-3}\right)$ is the porosity of the aquifer. The hydraulic gradient was calculated for each sampling event using the average of the water levels measured in the five piezometers of T1 and seven piezometers of T3 (Figure S1), similar to Manca, et al. [34]. Occasionally, it was not possible to calculate the hydraulic gradient due to missing water level measurements, and the average value of the hydraulic gradient $\left(0.045 \mathrm{~m} \mathrm{~m}^{-1}\right)$ observed during the monitoring was used for the calculation. Values of $K=2 \mathrm{~m} \mathrm{~d}^{-1}$, attributed to a sandy loam aquifer [60], and $\varphi_{a}$ $=0.41$, typical of sandy loam [61,62], were used for the calculation.

The NRR of the beds BR2-BR5 was calculated similarly to Warneke, et al. [63]:

$$
\mathrm{NRR}=\frac{\left(\Delta \mathrm{NO}_{3}^{-}\right)}{V_{\text {sat }}} \times Q
$$

where $\Delta \mathrm{NO}_{3}{ }^{-}\left(\mathrm{g} \mathrm{N} \mathrm{m}^{-3}\right)$ is the difference between the influent and effluent $\mathrm{NO}_{3}{ }^{-}$concentrations of the water samples at each sampling event, $Q\left(\mathrm{~m}^{3} \mathrm{~d}^{-1}\right)$ is the flow rate calculated at the time of each sampling using discharge rating curves, and $V_{\text {sat }}\left(\mathrm{m}^{3}\right)$ is the saturated 
volume of woodchip measured at the time of each sampling. Occasionally, $\mathrm{NO}_{3}{ }^{-}$was observed at higher concentrations at the effluent than the influent. When this occurred, the NRR was not calculated.

\subsection{Woodchip Saturation, Bed Flow Rate and Hydraulic Residence Time}

Pressure transducers (HOBO U20L-04, Onset, Bourne, MA, USA) were used to monitor the water levels of the bioreactors BR1, BR4 and BR5 on an hourly basis. The water levels were used to calculate the saturated woodchip section transmitting groundwater (BR1) and saturated woodchip volume (BR1, BR4 and BR5). It was not necessary to calculate the saturated woodchip volume of BR2 and BR3 as the woodchip was constantly saturated as per its design. Due to the duration of the monitoring ( $<3$ years), the volume of woodchip in the bioreactor was not replenished and was considered constant over time.

Pressure transducers were also installed in the outlet structure of BR2 and BR3 (Figures S2 and S3, respectively) and in the outlet piezometers of BR4 and BR5 (P4, in Figures S4 and S5) to log the depth of flow hourly. The depth of flow was related to the flow rates measured using a volumetric method (measuring vessel and a chronometer) at the outlet pipes of the beds, under unrestricted flow conditions and at different water flow stages.

The depths of flow and the flow rates measured for each bed were used to develop discharge rating curves, similar to previous studies [64,65].

The hydraulic residence time (HRT) of the wall BR1 was calculated both for the bottom (0.6 $\mathrm{m}$ width) and the top (1.4 $\mathrm{m}$ width):

$$
\mathrm{HRT}=\frac{s}{v}
$$

where $s(\mathrm{~m})$ is the width of the denitrification wall, and $v\left(\mathrm{~m} \mathrm{~d}^{-1}\right)$ is the groundwater velocity calculated with (4).

The HRT of the beds BR2-BR4 was calculated according to Christianson, et al. [66]:

$$
\mathrm{HRT}=\frac{V_{s a t} \times \varphi_{c}}{Q}
$$

where $V_{\text {sat }}\left(\mathrm{m}^{3}\right)$ is the saturated woodchip volume, $\varphi_{c}\left(\mathrm{~m}^{3} \mathrm{~m}^{-3}\right)$ is the macro porosity of the woodchip substrate, and $Q\left(\mathrm{~m}^{3} \mathrm{~d}^{-1}\right)$ is the bioreactor flow rate. A value of $\varphi_{c}=0.74$ was used for the calculation, similar to the value measured for softwood by Manca, et al. [34].

\subsection{Statistical Analysis}

Linear mixed model analysis was performed to assess the existence of significant differences between the transects T1 and T2 of the wall and the influent and effluent of the beds on internal parameters such as $\mathrm{pH}$ and $\mathrm{DO}$, as well as concentrations of $\mathrm{NO}_{3}{ }^{-}$ and $\mathrm{NH}_{4}{ }^{+}$, accounting for the repeated measurements over time. Linear mixed model analysis was performed using the R Package "Ime4" [67]. The Pearson coefficient $(r)$ and its significance $(p<0.05)$ was calculated to assess the degree of correlation between the daily average groundwater level (measured in the central piezometer of T1 using a pressure transducer) and the $\mathrm{NO}_{3}{ }^{-}$concentration of $\mathrm{BR} 1$ (measured in the piezometers, $\mathrm{n}=3$ ).

\section{Results and Discussion}

\subsection{Influent Nitrate and Removal Performance}

The significant difference $(p<0.05)$ in $\mathrm{NO}_{3}{ }^{-}$concentrations observed between $\mathrm{T} 1$ and $\mathrm{T} 2$ of the wall and influent and effluent of the beds (Figure 2a) confirms that all the bioreactors removed $\mathrm{NO}_{3}{ }^{-}$. Consequently, this research demonstrates the applicability of bioreactors to reduce $\mathrm{NO}_{3}{ }^{-}$in groundwater, subsurface water and irrigation tailwater on sugarcane farms in tropical climates. 


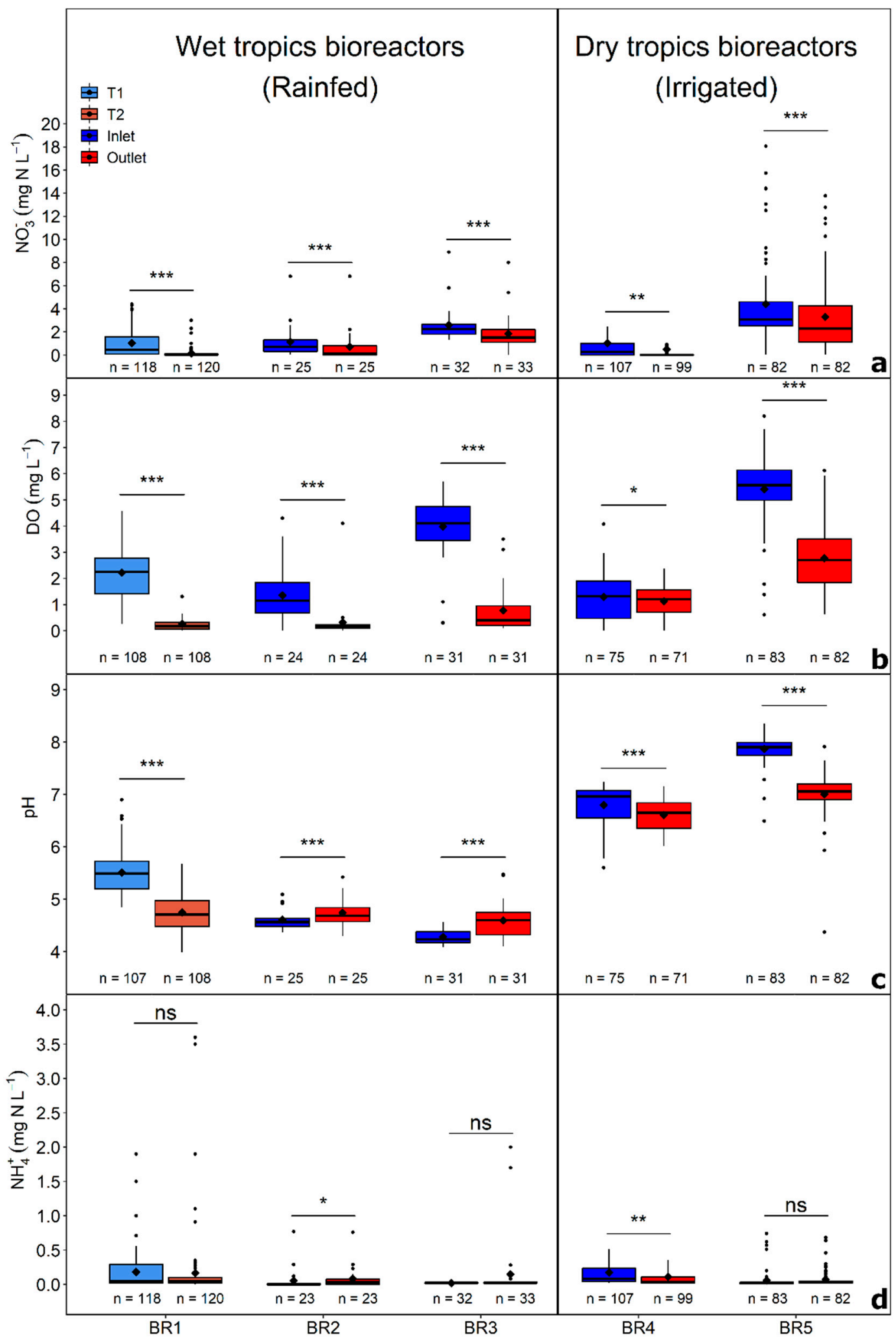

Figure 2. Boxplots of the $\mathrm{NO}_{3}{ }^{-}$concentration (a), dissolved oxygen (DO) (b) $\mathrm{pH}(\mathbf{c})$, and $\mathrm{NH}_{4}{ }^{+}$(d) measured in the up-gradient (T1) and wall (T2) transects of the wall BR1, and influent and effluent measured in the beds BR2-BR5. The solid line is the median, the black diamond is the mean, and black circles are the outliers. The sample count is displayed underneath each boxplot. The asterisks indicate statistical significance assessed with the linear mixed model (***:p<0.001; **: $p<0.01 ; *$ : $p<0.05 ;$ ns: not significant). 
The bioreactors were subject to different ranges of $\mathrm{NO}_{3}{ }^{-}$influent concentrations (Figure 2a). The wet tropics wall BR1 showed variable influent $\mathrm{NO}_{3}{ }^{-}$concentrations (Figure S6) that were positively correlated $(r=0.54, p<0.001)$ with the groundwater level, with higher concentrations detected at shallow groundwater levels, similar to what was observed in other denitrification walls in Queensland [34]. However, BR1 exhibited the lowest influent $\mathrm{NO}_{3}{ }^{-}$concentration (average $1.1 \mathrm{mg} \mathrm{N} \mathrm{L}^{-1}$ ) across wall studies (average reported range from 5.9 to $62.0 \mathrm{mg} \mathrm{N} \mathrm{L}^{-1}$ ) [29,33,34,68-70]. The maximum influent $\mathrm{NO}_{3}{ }^{-}$ concentration ( $4.4 \mathrm{mg} \mathrm{N} \mathrm{L}^{-1}$ ) was lower than the maximum concentration $\left(8.5 \mathrm{mg} \mathrm{N} \mathrm{L}^{-1}\right.$ ) observed in shallow groundwater under sugarcane farms in a nearby wet-tropics catchment [38]. The low influent $\mathrm{NO}_{3}{ }^{-}$concentrations together with the long HRT (average $7.5 \mathrm{~d}$, Figure 3a) resulted in $\mathrm{NO}_{3}{ }^{-}$limitation within the wall (T2, average $\mathrm{NO}_{3}{ }^{-}$concentration $\left.0.1 \mathrm{mg} \mathrm{N} \mathrm{L}^{-1}\right)$, contributing to a low average NRR value $\left(0.15 \mathrm{~g} \mathrm{~N} \mathrm{~m}^{-3} \mathrm{~d}^{-1}\right)$. This $\mathrm{NRR}$ is lower than values reported in previous $\mathrm{NO}_{3}{ }^{-}$-limited walls installed in southeast Queensland and New Zealand (from 1.4 to $2.0 \mathrm{~g} \mathrm{~N} \mathrm{~m}^{-3} \mathrm{~d}^{-1}$ ) [34,68], likely due to the low influent $\mathrm{NO}_{3}{ }^{-}$concentrations at BR1 (compared to a maximum $21 \mathrm{mg} \mathrm{N} \mathrm{L}^{-1}$ recorded at the other walls). As expected, the NRR of BR1 was the lowest across the trials (Figure 3b), as walls usually produce NRR an order of magnitude lower than beds [1], due to the slower movement of groundwater in a wall (groundwater flow rate in BR1 averaged $6.7 \mathrm{~m}^{3} \mathrm{~d}^{-1}$ ) compared to the subsurface tile-drainage water or irrigation tailwater flowing through the beds (Figure 3c).

The influent $\mathrm{NO}_{3}{ }^{-}$concentration entering the wet tropics tile-drainage beds BR2 and BR3 was relatively constant, with maximum $\mathrm{NO}_{3}{ }^{-}$concentrations $\left(6.8\right.$ and $8.9 \mathrm{mg} \mathrm{N} \mathrm{L}^{-1}$, respectively) occurring after $\mathrm{N}$ fertilizer application (Figure S7). However, the average influent $\mathrm{NO}_{3}{ }^{-}$concentrations (1.1 and $2.6 \mathrm{mg} \mathrm{N} \mathrm{L}^{-1}$, respectively, Figure 2a) were at the lower range (from 1.2 to $15.2 \mathrm{mg} \mathrm{N} \mathrm{L}^{-1}$ ) when compared to tile-drainage beds installed in the U.S. and New Zealand $[22,27,31]$. Despite the low influent concentrations, $\mathrm{NO}_{3}{ }^{-}$ limitation in BR2 and BR3 was rarely observed as a consequence of relatively short HRT (average of 2.2 and $5.6 \mathrm{~h}$, for BR2 and BR3, respectively Figure 3a), with average NRR values of 4.3 and $2.5 \mathrm{~g} \mathrm{~N} \mathrm{~m}^{-3} \mathrm{~d}^{-1}$, respectively (Figure 3b). The higher NRR of BR2 compared to BR3 was related to the higher flow rate (average of 121.9 and $48.3 \mathrm{~m}^{3} \mathrm{~d}^{-1}$, respectively, Figure $3 c$ ) that was calculated with the discharge rating curves (Figure S8). The higher flow rate of BR2 was a consequence of the larger tile-drained catchment area (Table 1) that supplied the inlet and the shorter HRT, with a greater volume of influent water entering and being treated in the bioreactor over time. This short HRT was important for reducing the risk of nitrate limitation. The average values of NRR were in the mid-range (from 0.2 to $7.8 \mathrm{~g} \mathrm{~N} \mathrm{~m}^{-3} \mathrm{~d}^{-1}$ ) of the NRR of tile-drainage beds installed in humid continental and humid subtropical climates in the U.S. [22,27].

The flow rate of the dry tropics beds BR4 and BR5, calculated with the discharge rating curves (Figure S8), showed similar values to BR3 (average of 49.7 and $57.3 \mathrm{~m}^{3} \mathrm{~d}^{-1}$, respectively; Figure 3c), despite their volumes being twice as large. The flow rate of BR4 was reduced during the first two irrigations (Figure S9) due to a blockage of the geo-fabric used on the inlet. This was rectified by puncturing the geofabric, after which, the flow rate reached its maximum. The influent $\mathrm{NO}_{3}{ }^{-}$concentrations of the beds BR4 and BR5 varied over time, with the maximum value $\left(18.1 \mathrm{mg} \mathrm{N} \mathrm{L}^{-1}\right)$ being lower than those reported in sugarcane irrigation runoff in the Lower Burdekin catchment $\left(\sim 25 \mathrm{mg} \mathrm{N} \mathrm{L}^{-1}\right)$ [5]. 


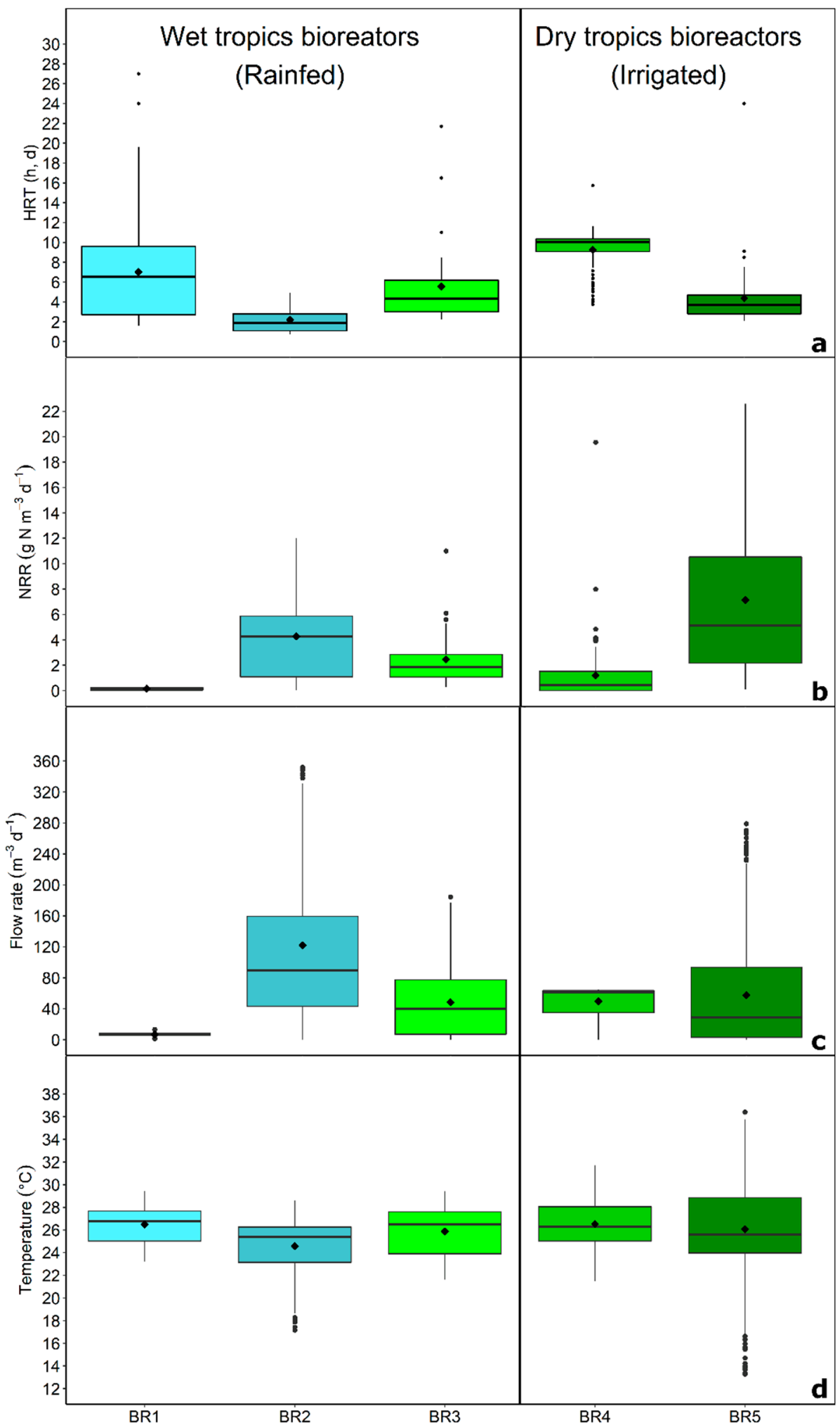

Figure 3. Boxplots of hydraulic residence time (HRT, a), $\mathrm{NO}_{3}{ }^{-}$removal rate $(\mathrm{NRR}, \mathbf{b})$, flow rate (c), and temperature (d) of the wall BR1, and the beds BR2-BR5. Note that the HRT of the wall BR1 is expressed in days (d), whereas the HRT of the beds BR2-BR5 is expressed in hours (h). The temperature was measured using pressure transducers installed in the wall transect (T2) of BR1, in the outlet structures of BR2 and BR3, and in the outlet piezometers of BR4 and BR5. The solid line is the median, the black diamond is the mean, and black circles are the outliers. 
The irrigation water source had a significant influence on the influent $\mathrm{NO}_{3}{ }^{-}$concentrations, and hence on the $\mathrm{NO}_{3}{ }^{-}$removal performance of the bioreactors. The bed BR4 showed a low influent $\mathrm{NO}_{3}{ }^{-}$(average $1.0 \mathrm{mg} \mathrm{N} \mathrm{L}^{-1}$, Figure 2a) due to the use of the Haughton River water for irrigation, which usually results in concentrations $<1.0 \mathrm{mg} \mathrm{N} \mathrm{L}^{-1}$ [71]. The low influent $\mathrm{NO}_{3}{ }^{-}$concentration, as well as the extended HRT (average of $9.2 \mathrm{~h}$, Figure 3a), resulted in $\mathrm{NO}_{3}{ }^{-}$limitation in BR4, with an average NRR of $1.2 \mathrm{~g} \mathrm{~N} \mathrm{~m}^{-3} \mathrm{~d}^{-1}$ (Figure 3b). This NRR was still higher than a $\mathrm{NO}_{3}{ }^{-}$-limited in-stream bed of a similar size $\left(40 \mathrm{~m}^{3}\right.$; average NRR from 0.1 to $0.6 \mathrm{~g} \mathrm{~N} \mathrm{~m}^{-3} \mathrm{~d}^{-1}$ ) installed in Canada [72], probably due to the higher tropical temperatures, and hence, faster denitrification. In contrast, at BR5 groundwater (with concentrations of 2-3 $\mathrm{mg} \mathrm{N} \mathrm{L}^{-1}$ ) was primarily used for irrigating the sugarcane. This contributed to a relatively high and consistent influent $\mathrm{NO}_{3}{ }^{-}$concentration entering the bed BR5 (average of $4.4 \mathrm{mg} \mathrm{N} \mathrm{L}^{-1}$, Figure 2a). Nitrate concentrations $>5.0 \mathrm{mg} \mathrm{N} \mathrm{L}^{-1}$ have been observed in groundwater at the Lower Burdekin catchment [41]. The combination of higher $\mathrm{NO}_{3}{ }^{-}$concentrations and short HRT (average $4.4 \mathrm{~h}$, Figure 3a) produced the highest NRR (average $7.1 \mathrm{~g} \mathrm{~N} \mathrm{~m}^{-3} \mathrm{~d}^{-1}$, Figure $3 \mathrm{~b}$ ) of all of the bioreactors reported in this study, and was significantly higher than the NRR of $0.97 \mathrm{~g} \mathrm{~N} \mathrm{~m}^{-3} \mathrm{~d}^{-1}$ observed in a ditch diversion bioreactor installed in the U.S [29].

These results illustrate the importance of site selection for the installation of bioreactors, even under similar cropping systems. For both beds and walls, it is important to identify sites characterized by relatively high and consistent $\mathrm{NO}_{3}{ }^{-}$concentrations $\left(>3.0 \mathrm{mg} \mathrm{N} \mathrm{L}^{-1}\right)$ to maximise the NRR performance. In the dry tropics, the source of irrigation water and its $\mathrm{NO}_{3}{ }^{-}$concentration can significantly impact the NRR of beds treating tailwater. Therefore, bioreactors should be prioritised on farms that irrigate using groundwater with elevated $\mathrm{NO}_{3}{ }^{-}$concentrations.

The NRR was also influenced by flow rate and HRT. For tile-drained beds in the wet tropics, larger tile-drained catchments can provide a higher flow rate and consequently increase the NRR. Where influent $\mathrm{NO}_{3}{ }^{-}$concentrations are relatively low, the bioreactor bed should be designed and sized for a short HRT to avoid $\mathrm{NO}_{3}{ }^{-}$limitation.

\subsection{Nitrate Removal Processes}

Low DO concentrations, a suitable $\mathrm{pH}$ range, presence of carbon and non- $\mathrm{NO}_{3}{ }^{-}$ limiting conditions are required for denitrification to occur as the dominant $\mathrm{NO}_{3}{ }^{-}$removal process and to avoid pollutant swapping [73].

The flow of water across the woodchip of both the wet and dry tropics bioreactors produced a significant reduction $(p<0.05)$ in DO concentrations between influent and effluent (Figure 2b). Most of the bioreactors (BR1-BR4) showed ideal DO concentrations for denitrification, which usually occurs at $\mathrm{DO}<2.0 \mathrm{mg} \mathrm{L}^{-1}$ [73]. Only BR5 exhibited a relatively high effluent DO (average $2.8 \mathrm{mg} \mathrm{L}^{-1}$ ), a likely consequence of the short HRT of BR5 (average $4.4 \mathrm{~h}$, Figure 3a) and high influent DO concentrations (average $5.4 \mathrm{mg} \mathrm{L}^{-1}$ ). Analyses of dissolved $\mathrm{N}_{2} \mathrm{O}$ of the influent and effluent water of BR5 [74] showed that there was not significant production of $\mathrm{N}_{2} \mathrm{O}_{\text {dis }}$ across the bioreactor, suggesting that complete denitrification was occurring even with $\mathrm{DO}$ concentrations $>2.0 \mathrm{mg} \mathrm{L}^{-1}$. The occurrence of denitrification at $\mathrm{DO}>2.0 \mathrm{mg} \mathrm{L}^{-1}$ was also observed in another pilot-scale bioreactor filled with rice-straw at temperatures $>21^{\circ} \mathrm{C}$, HRT of $24 \mathrm{~h}$ and at $10-15 \mathrm{mg} \mathrm{N} \mathrm{L}^{-1}$ influent concentrations [75].

The influent water of the wet tropics bioreactors was acidic throughout the monitoring, with the lowest value in the influent tile-drainage water entering BR2 and BR3 (average $\mathrm{pH} 4.6$ and 4.3, respectively; Figure 2c), and more neutral $\mathrm{pH}$ values measured in the groundwater flowing into the wall BR1 (average $\mathrm{pH}$ 5.5). The flow of water across the woodchip of these bioreactors affected the $\mathrm{pH}$. In the wall BR1, there was a significant reduction $(p<0.05)$ in the $\mathrm{pH}$ between $\mathrm{T} 1$ and $\mathrm{T} 2$, likely due to the use of hardwood as a filling material. This $\mathrm{pH}$ reduction was similar to that observed in a wall filled with hardwood woodchip in southeast Queensland [34], likely due to the release of high dissolved organic carbon [76]. The beds BR2 and BR3 experienced a significant increase 
$(p<0.05)$ in $\mathrm{pH}$ between the inlet and outlet. This trend was similar to that observed in a denitrification bed filled with softwood woodchip receiving slightly acidic effluent $(\mathrm{pH}=6)$ from a hydroponic glasshouse in New Zealand, probably due to the release of hydroxyl ions during denitrification [77]. The influent of the dry tropics beds BR4 and BR5 was close to neutral (average $\mathrm{pH} 6.8$ and 7.9, respectively, Figure 2c). The flow of water across the woodchip also affected the $\mathrm{pH}$ values, with a significant decrease $(p<0.05)$ between the inlet and outlet, likely as a consequence of organic acids produced from biodegradation of the woodchips [78]. Despite the $\mathrm{pH}$ being low, denitrification would have been supported considering the relatively high average temperatures, which were $>25^{\circ} \mathrm{C}$ in all the bioreactors (Figure $3 \mathrm{~d}$ ). These are the highest temperatures reported across bioreactor studies [1,14].

Further evidence that denitrification was the dominant $\mathrm{NO}_{3}{ }^{-}$removal process comes from the limited occurrence of dissimilatory nitrate reduction to ammonium (DNRA), as production of $\mathrm{NH}_{4}{ }^{+}$was not observed in the majority of the bioreactors, except for BR2, where a significant increase $p<0.001$ ) was detected at the outlet (Figure 2d). The production of DNRA has been observed in woodchip bioreactors treating aquaculture systems [79] and laboratory column experiments [80], at high dissolved organic carbon concentrations when $\mathrm{NO}_{3}{ }^{-}$becomes limited [81]. However, $\mathrm{NO}_{3}{ }^{-}$limitation was not observed in BR2, and the production of $\mathrm{NH}_{4}{ }^{+}$in this bioreactor is more likely to have occurred as a consequence of ammonification of organic $\mathrm{N}$ compounds in the woodchip [82]. Furthermore, the low production of $\mathrm{NH}_{4}{ }^{+}\left(<0.1 \mathrm{mg} \mathrm{N} \mathrm{L}^{-1}\right)$ observed in the bed BR2 (Figure $2 \mathrm{~d}$ ) is not a concern in terms of pollution swapping, due to its low concentration.

This study shows that despite the variability in $\mathrm{DO}$ and $\mathrm{pH}$ across the sites, denitrification was the dominant $\mathrm{NO}_{3}{ }^{-}$removal process occurring in the wet tropics and dry tropics bioreactors.

\section{Conclusions}

Different designs of woodchip bioreactors (one wall and four beds) were trialled in sugar cane production systems adjacent to the GBR, in wet tropical and dry tropical climates subject to different hydrological regimes. The bioreactors in the wet tropics treated both shallow groundwater and subsurface tile-drainage water from sugarcane crops that were rain-fed. Conversely, the bioreactors in the dry tropics treated irrigation tailwater from irrigated sugarcane crops. All of the bioreactors proved effective at removing $\mathrm{NO}_{3}{ }^{-}$, with the denitrification beds producing a higher NRR than the wall. The highest NRR performance was observed in the dry tropics bed BR5, due to a higher, more consistent influent $\mathrm{NO}_{3}{ }^{-}$concentration from the elevated $\mathrm{NO}_{3}{ }^{-}$in the groundwater used to irrigate the crop. This study demonstrated that bioreactors are effective at reducing $\mathrm{NO}_{3}{ }^{-}$from sugarcane production systems in tropical climates. A range of different designs can be adapted to diverse hydrological regimes and tropical climates to reduce $\mathrm{NO}_{3}{ }^{-}$runoff to the GBR. Preliminary monitoring is recommended to assess the $\mathrm{NO}_{3}{ }^{-}$concentration of groundwater, tile-drainage water or irrigation water, to identify areas with elevated $\mathrm{NO}_{3}{ }^{-}$concentrations for siting bioreactors to maximise the $\mathrm{NO}_{3}{ }^{-}$removal performance of the bioreactors.

Supplementary Materials: The following are available online at https:/ /www.mdpi.com/article/10 $.3390 / w 13243608 /$ s1, Figure S1: Schematic of the wall BR1, Figure S2: Schematic of the off-line bed BR2, Figure S3: Schematic of the off-line bed BR3, Figure S4: Schematic of the in-line bed BR4, Figure S5: Schematic of the in-line bed BR5, Figure S6: Rainfall, groundwater flow rate, $\mathrm{NO}_{3}{ }^{-}$concentrations and standard deviation of the water samples $(n=3)$ collected from the up-gradient (T1) and wall (T2) transects of the wall BR1, Figure S7: Rainfall, flow rate, and $\mathrm{NO}_{3}{ }^{-}$concentrations of the influent (inlet) and effluent (outlet) water samples collected from the beds BR2 and BR3, Figure S8: Discharge rating curves calculated for the beds BR2 (a), BR3 (b), BR4 (c), and BR5 (d), Figure S9: Flow rate of the beds $\mathrm{BR} 4$ and $\mathrm{BR} 5$, and $\mathrm{NO}_{3}{ }^{-}$concentrations of the influent (inlet) and effluent (outlet) water samples collected from the bed BR5.

Author Contributions: Conceptualization, F.M., C.W., R.R., S.A., and P.G.; Methodology, F.M., C.W., R.R., S.A., L.S., and P.G.; Validation, M.G., D.R., L.S., and P.G.; formal analysis, F.M., and D.D.R.; 
investigation, F.M., S.A., and C.A.; resources, F.G., D.R., and P.G.; data curation. F.M., S.A., and C.A., writing-original draft preparation, F.M. and P.G.; writing-review and editing, F.M., C.W., R.R., S.A., C.A., D.D.R., M.G., F.G., D.R., L.S., and P.G.; visualization, F.M.; supervision, C.W., M.G., F.G., D.R., and P.G.; project administration, C.W., F.G., and P.G.; funding acquisition, C.W. and P.G. All authors have read and agreed to the published version of the manuscript.

Funding: Funding for the trials was from the Queensland Reef Water Quality Program, under the auspices of the Wet Tropics Major Integrated Project and Innovation Fund.

Institutional Review Board Statement: Not applicable.

Informed Consent Statement: Not applicable.

Data Availability Statement: The data presented in this study is available on request from the corresponding authors.

Acknowledgments: The authors acknowledge the contribution of the landholders and staff involved in the bioreactor trials throughout Queensland, including staff from the Department of Agriculture and Fisheries, Queensland University of Technology, Bbifmac Inc., Terrain NRM, Australian Wetlands Consulting, Department of Environment and Science and James Cook University for design, monitoring, maintenance and analysis. A special thanks goes to René Ferretti for the moral support provided throughout the research.

Conflicts of Interest: The authors declare no conflict of interest. The funders had no role in the design of the study; in the collection, analyses, or interpretation of data; in the writing of the manuscript, or in the decision to publish the results.

\section{References}

1. Schipper, L.A.; Robertson, W.D.; Gold, A.J.; Jaynes, D.B.; Cameron, S.G. Denitrifying bioreactors-An approach for reducing nitrate loads to receiving waters. Ecol. Eng. 2010, 36, 1532-1543. [CrossRef]

2. $\quad$ Erisman, J.W.; Galloway, J.N.; Seitzinger, S.; Bleeker, A.; Dise, N.B.; Petrescu, A.M.R.; Leach, A.M.; de Vries, W. Consequences of human modification of the global nitrogen cycle. Philos. Trans. R. Soc. B 2013, 368, 20130116. [CrossRef]

3. Howarth, R.W. Coastal nitrogen pollution: A review of sources and trends globally and regionally. Harmful Algae 2008, 8, 14-20. [CrossRef]

4. Waterhouse, J.; Brodie, J.; Tracey, D.; Smith, R.; Vandergragt, M.; Collier, C.; Petus, C.; Baird, M.; Kroon, F.; Mann, R.; et al. Chapter 3: The risk from anthropogenic pollutants to Great Barrier Reef coastal and marine ecosystems. In Scientific Consensus Statement 2017: A Synthesis of the Science of Land-Based Water Quality Impacts on the Great Barrier Reef; State of Queensland: Brisbane, QLD, Australia, 2017; p. 186.

5. Thorburn, P.J.; Biggs, J.S.; Attard, S.J.; Kemei, J. Environmental impacts of irrigated sugarcane production: Nitrogen lost through runoff and leaching. Agric. Ecosyst. Environ. 2011, 144, 1-12. [CrossRef]

6. Waterhouse, J.; Brodie, J.; Lewis, S.; Mitchell, A. Quantifying the sources of pollutants in the Great Barrier Reef catchments and the relative risk to reef ecosystems. Mar. Pollut. Bull. 2012, 65, 394-406. [CrossRef] [PubMed]

7. Hoey, J.; Campbell, M.L.; Hewitt, C.L.; Gould, B.; Bird, R. Acanthaster planci invasions: Applying biosecurity practices to manage a native boom and bust coral pest in Australia. Manage. Biol. Invasion. 2016, 7, 213-220. [CrossRef]

8. De'ath, G.; Fabricius, K.E.; Sweatman, H.; Puotinen, M. The 27-year decline of coral cover on the Great Barrier Reef and its causes. Proc. Natl. Acad. Sci. USA 2012, 109, 17995-17999. [CrossRef]

9. Christianson, L.E.; Cooke, A.C.; Hay, C.; Helmers, M.; Feyereisen, G.; Ranaivoson, A.; McMaine, J.; McDaniel, R.; Rosen, T.; Pluer, W.; et al. Effectiveness of denitrifying bioreactors on water pollutant reduction from agricultural areas. Trans. ASABE 2021, 64, 641-658. [CrossRef]

10. Groffman, P.M.; Rosi-Marshall, E.J. The Nitrogen Cycle. In Fundamentals of Ecosystem Science; Academic Press: Cambridge, MA, USA, 2012; pp. 137-158.

11. Christianson, L.E.; Helmers, M.J. Woodchip Bioreactors for Nitrate in agricultural Drainage; Agriculture and Environment Extension Publications: Ames, IA, USA, 2011.

12. DES. Bioreactors. Available online: https://wetlandinfo.des.qld.gov.au/wetlands/management/treatment-systems/foragriculture/treatment-sys-nav-page/bioreactors/ (accessed on 24 October 2021).

13. Manca, F.; De Rosa, D.; Reading, L.P.; Rowlings, D.W.; Scheer, C.; Schipper, L.A.; Grace, P.R. Effect of soil cap and nitrate inflow on nitrous oxide emissions from woodchip bioreactors. Ecol. Eng. 2021, 166, 106235. [CrossRef]

14. Addy, K.; Gold, A.J.; Christianson, L.E.; David, M.B.; Schipper, L.A.; Ratigan, N.A. Denitrifying bioreactors for nitrate removal: A meta-analysis. J. Environ. Qual. 2016, 45, 873-881. [CrossRef]

15. Hoover, N.L.; Bhandari, A.; Soupir, M.L.; Moorman, T.B. Woodchip denitrification bioreactors: Impact of temperature and hydraulic retention time on nitrate removal. J. Environ. Qual. 2016, 45, 803-812. [CrossRef] 
16. Braker, G.; Schwarz, J.; Conrad, R. Influence of temperature on the composition and activity of denitrifying soil communities. FEMS Microbiol. Ecol. 2010, 73, 134-148. [CrossRef]

17. Cameron, S.G.; Schipper, L.A. Nitrate removal and hydraulic performance of organic carbon for use in denitrification beds. Ecol. Eng. 2010, 36, 1588-1595. [CrossRef]

18. Hassanpour, B.; Giri, S.; Pluer, W.T.; Steenhuis, T.S.; Geohring, L.D. Seasonal performance of denitrifying bioreactors in the Northeastern United States: Field trials. J. Environ. Manag. 2017, 202, 242-253. [CrossRef] [PubMed]

19. USEPA. Northern Gulf of Mexico Hypoxic Zone. Available online: https://www.epa.gov/ms-htf/northern-gulf-mexico-hypoxiczone (accessed on 14 October 2019).

20. Woli, K.P.; David, M.B.; Cooke, R.A.; McIsaac, G.F.; Mitchell, C.A. Nitrogen balance in and export from agricultural fields associated with controlled drainage systems and denitrifying bioreactors. Ecol. Eng. 2010, 36, 1558-1566. [CrossRef]

21. David, M.B.; Gentry, L.E.; Cooke, R.A.; Herbstritt, S.M. Temperature and substrate control woodchip bioreactor performance in reducing tile nitrate loads in east-central Illinois. J. Environ. Qual. 2016, 45, 822-829. [CrossRef]

22. Christianson, L.E.; Bhandari, A.; Helmers, M.J.; Kult, K.J.; Sutphin, T.; Wolf, R. Performance evaluation of four field-scale agricultural drainage denitrification bioreactors in Iowa. Trans. ASABE 2012, 55, 2163-2174. [CrossRef]

23. Christianson, L.E.; Helmers, M.J.; Bhandari, A.; Moorman, T.B. Internal hydraulics of an agricultural drainage denitrification bioreactor. Ecol. Eng. 2013, 52, 298-307. [CrossRef]

24. Ranaivoson, A.; Rice, P.; Moncrief, J.; Feyereisen, G.; Dittrich, M. Acetochlor and atrazine dissipation in a woodchip denitrifying bioreactor: A comparison of experimental results with model estimates. Ecol. Eng. 2019, 3, 286-306. [CrossRef]

25. Ranaivoson, A.; Moncrief, J.; Venterea, R.; Rice, P.; Dittrich, M. Report to the Minnesota Department of Agriculture: Anaerobic Woodchip Bioreactor for Denitrification, Herbicide Dissipation, and Greenhouse Gas Mitigation. MDA Bioreactor Report 2012. pp. 1-17. Available online: https:/ / www.mda.state.mn.us/sites/default/files/inline-files/bioreactor2012.pdf (accessed on 1 June 2021).

26. Partheeban, C. Demonstrating the Effectiveness of Nitrate-Nitrogen Removal of Denitrifying Bioreactors in South Dakota for Improved Drainage Water Management; Agricultural and Biosystems Engineering Department, South Dakota State University: Brookings, SD, USA, 2014.

27. Rosen, T.; Christianson, L. Performance of denitrifying bioreactors at reducing agricultural nitrogen pollution in a humid subtropical coastal plain climate. Water 2017, 9, 112. [CrossRef]

28. Bock, E.M.; Coleman, B.S.L.; Easton, Z.M. Performance of an under-loaded denitrifying bioreactor with biochar amendment. J. Environ. Manage. 2018, 217, 447-455. [CrossRef]

29. Christianson, L.E.; Collick, A.S.; Bryant, R.B.; Rosen, T.; Bock, E.M.; Allen, A.L.; Kleinman, P.J.A.; May, E.B.; Buda, A.R.; Robinson, J. Enhanced Denitrification Bioreactors Hold Promise for Mid-Atlantic Ditch Drainage. Agric. Environ. Lett. 2017, 2, 1-5. [CrossRef]

30. Schipper, L.A.; Vojvodić-Vuković, M. Nitrate removal from groundwater using a denitrification wall amended with sawdust: Field trial. J. Environ. Qual. 1998, 27, 664-668. [CrossRef]

31. Rivas, A.; Barkle, G.; Stenger, R.; Moorhead, B.; Clague, J. Nitrate removal and secondary effects of a woodchip bioreactor for the treatment of subsurface drainage with dynamic flows under pastoral agriculture. Ecol. Eng. 2020, 148, 105786. [CrossRef]

32. Schipper, L.A.; Cameron, S.G.; Warneke, S. Nitrate removal from three different effluents using large-scale denitrification beds. Ecol. Eng. 2010, 36, 1552-1557. [CrossRef]

33. Fahrner, S. Groundwater Nitrate Removal using a Bioremediation Trench. Honours Thesis, University of Western Australia, Crawley, WA, Australia, 2002.

34. Manca, F.; De Rosa, D.; Reading, L.P.; Rowlings, D.W.; Scheer, C.; Layden, I.; Irvine-Brown, S.; Schipper, L.A.; Grace, P.R. Nitrate removal and greenhouse gas production of woodchip denitrification walls under a humid subtropical climate. Ecol. Eng. 2020, 156, 1-10. [CrossRef]

35. Wegscheidl, C.; Robinson, R.; Manca, F. Using Denitrifying Bioreactors to Improve Water Quality on Queensland Farms; Queensland Government, Department of Agriculture and Fisheries: Townsville, QLD, Australia, 2021.

36. QDAF. Bioreactors: Key aspects for Effective Design, Operation and Monitoring-Interim Guideline for Bioreactor Trials July 2018; QDAF: Brisbane, QLD, Australia, 2018.

37. Rasiah, V.; Armour, J.D.; Cogle, A.L. Assessment of variables controlling nitrate dynamics in groundwater: Is it a threat to surface aquatic ecosystems? Mar. Pollut. Bull. 2005, 51, 60-69. [CrossRef]

38. Stanley, J.; Reading, L. Nitrate dynamics in groundwater under sugarcane in a wet-tropics catchment. Heliyon 2020, 6, e05507. [CrossRef] [PubMed]

39. Rasiah, V.; Armour, J.D.; Nelson, P.N. Nitrate in shallow fluctuating groundwater under sugarcane: Quantifying the lateral export quantities to surface waters. Agric. Ecosyst. Environ. 2013, 180, 103-110. [CrossRef]

40. Lenahan, M.; Bristow, K. Understanding sub-surface solute distributions and salinization mechanisms in a tropical coastal floodplain groundwater system. J. Hydrol. 2010, 390, 131-142. [CrossRef]

41. Thayalakumaran, T.; Bristow, K.; Charlesworth, P.; Fass, T. Geochemical conditions in groundwater systems: Implications for the attenuation of agricultural nitrate. Agric. Water Manage. 2008, 95, 103-115. [CrossRef]

42. Thorburn, P.J.; Biggs, J.S.; Weier, K.L.; Keating, B.A. Nitrate in groundwaters of intensive agricultural areas in coastal Northeastern Australia. Agric. Ecosyst. Environ. 2003, 94, 49-58. [CrossRef] 
43. Qureshi, M.E.; Wegener, M.K.; Bristow, K.L.; Harrison, S.R. Economic evaluation of alternative irrigation systems for sugarcane in the Burdekin delta in north Queensland, Australia. WIT Trans. Ecol. Environ. 2001, 48, 1-11. [CrossRef]

44. Peel, M.C.; Finlayson, B.L.; Mcmahon, T.A. Updated world map of the Köppen-Geiger climate classification. Hydrol. Earth Syst. Sci. 2007, 11, 1633-1644. [CrossRef]

45. BoM. Regional Weather and Climate Guide-The Wet Tropics. 2019. Available online: http://www.bom.gov.au/climate/climateguides / guides / 027-Wet-Tropics-QLD-Climate-Guide.pdf (accessed on 1 June 2021).

46. BOM. Johnstone Catchment Water Quality Targets. Available online: https://www.reefplan.qld.gov.au/_data/assets/pdf_file/ 0018/46062/catchment-targets-wet-tropics-johnstone.pdf (accessed on 1 June 2021).

47. BOM. Tully Catchment Water Quality Targets. Available online: https://www.reefplan.qld.gov.au/_data/assets/pdf_file/0022 /46066/ catchment-targets-wet-tropics-tully.pdf (accessed on 1 June 2021).

48. McInnes, K.; Abbs, D.; Bhend, J.; Chiew, F.; Church, J.; Ekstrm, M.; Kirono, D.; Lenton, A.; Lucas, C.; Moise, A. Wet Tropics Cluster Report; CSIRO and Bureau of Meteorology: Melbourne, VIC, Australia, 2015; p. 54.

49. BoM. Regional Weather and Climate Guide-The Burdekin. 2019. Available online: http://www.bom.gov.au/climate/climateguides / guides/022-Burdekin-QLD-Climate-Guide.pdf (accessed on 1 June 2021).

50. BOM. Burdekin Catchment Water Quality Targets. Available online: https://www.reefplan.qld.gov.au/_data/assets/pdf_file/ 0015/46032/catchment-targets-burdekin-burdekin.pdf (accessed on 1 June 2021).

51. BOM. Haughton Catchment Water Quality Targets. Available online: https://www.reefplan.qld.gov.au/_data/assets/pdf_file/ 0017/46034/catchment-targets-burdekin-haughton.pdf (accessed on 1 June 2021).

52. Petheram, C.; Tickell, S.; O'Gara, F.; Bristow, K.L.; Smith, A.; Jolly, P. Analysis of the Lower Burdekin, Ord and Katherine-Douglas-Daly Irrigation Areas: Implications to Future Design and Management of Tropical Irrigation; CSIRO and CRC for Irrigation Futures: Canberra, ACT, Australia, 2008.

53. Holden, J.; McGuire, P. Irrigation of Sugarcane Manual; Sugar Research Australia: Indooroopilly, QLD, Australia, $2014 ;$ p. 64.

54. ANZECC; ARMCANZ. Australian and New Zealand Guidelines for Fresh and Marine Water Quality; Australian and New Zealand Environment and Conservation Council and Agriculture and Resource Management Council of Australia and New Zealand: Canberra, ACT, Australia, 2000; Volume 2, p. 678.

55. Weiss, R.F. The solubility of nitrogen, oxygen and argon in water and seawater. Deep Sea Res. Oceanogr. Abstr. 1970, 17, 721-735. [CrossRef]

56. Schipper, L.A.; Vojvodić-Vuković, M. Nitrate removal from groundwater and denitrification rates in a porous treatment wall amended with sawdust. Ecol. Eng. 2000, 14, 269-278. [CrossRef]

57. Cameron, S.G.; Schipper, L.A. Hydraulic properties, hydraulic efficiency and nitrate removal of organic carbon media for use in denitrification beds. Ecol. Eng. 2012, 41,1-7. [CrossRef]

58. Hua, G.; Salo, M.W.; Schmit, C.G.; Hay, C.H. Nitrate and phosphate removal from agricultural subsurface drainage using laboratory woodchip bioreactors and recycled steel byproduct filters. Water Res. 2016, 102, 180-189. [CrossRef] [PubMed]

59. Darcy, H. Les Fontaines Publiques de la Ville de Dijon: Exposition et Application; Victor Dalmont: Batignolles, France, 1856.

60. Cheesman, A.; Bithin, D.; Nelson, P. Johnstone Bioreactor Site 01 Initial Data Assessment; James Cook University: Douglas, QLD, Australia, 2019; p. 25.

61. Ohio-EPA. Characterization of Site Hydrogeology. Tech. Guid. Ground Water Investig. 2006, 3, 67.

62. Rawls, W.J.; Brakensiek, D.L.; Miller, N. Green-Ampt infiltration parameters from soils data. J. Hydraul. Eng. 1983, 109, 62-70. [CrossRef]

63. Warneke, S.; Schipper, L.A.; Bruesewitz, D.A.; Baisden, W.T. A comparison of different approaches for measuring denitrification rates in a nitrate removing bioreactor. Water Res. 2011, 45, 4141-4151. [CrossRef] [PubMed]

64. Chun, J.A.; Cooke, R.A. Calibrating Agridrain water level control structures using generalized weir and orifice equations. Appl. Eng. Agric. 2008, 24, 595-602. [CrossRef]

65. Chun, J.A.; Cooke, R.A.; Eheart, J.W.; Cho, J. Estimation of flow and transport parameters for woodchip-based bioreactors: II. field-scale bioreactor. Biosys. Eng. 2010, 105, 95-102. [CrossRef]

66. Christianson, L.E.; Bhandari, A.; Helmers, M.J. Pilot-scale evaluation of denitrification drainage bioreactors: Reactor geometry and performance. J. Environ. Eng. 2011, 137, 213-220. [CrossRef]

67. Pinheiro, J.; Bates, D.; DebRoy, S.; Sarkar, D.; Team, R.C. nlme: Linear and Nonlinear Mixed Effects Models. R Package version 3.1-140. 2019. Available online: https://svn.r-project.org/R-packages/trunk/nlme/ (accessed on 1 June 2021).

68. Schipper, L.A.; Barkle, G.F.; Vojvodic-Vukovic, M. Maximum rates of nitrate removal in a denitrification wall. J. Environ. Qual. 2005, 34, 1270-1276. [CrossRef] [PubMed]

69. Robertson, W.D.; Blowes, D.W.; Ptacek, C.J.; Cherry, J.A. Long-term performance of in situ reactive barriers for nitrate remediation. Groundwater 2000, 38, 689-695. [CrossRef]

70. Schmidt, C.A.; Clark, M.W. Efficacy of a denitrification wall to treat continuously high nitrate loads. Ecol. Eng. 2012, 42, 203-211. [CrossRef]

71. Congdon, R.; Lukacs, G. Water quality aspects of irrigation runoff from the Burdekin River irrigation area. In Downstream Effects of Land Use; Department of Natural Resources: Townsville, QLD, Australia, 1996; pp. 73-76.

72. Elgood, Z.; Robertson, W.D.; Schiff, S.L.; Elgood, R. Nitrate removal and greenhouse gas production in a stream-bed denitrifying bioreactor. Ecol. Eng. 2010, 36, 1575-1580. [CrossRef] 
73. Rivett, M.O.; Buss, S.R.; Morgan, P.; Smith, J.W.N.; Bemment, C.D. Nitrate attenuation in groundwater: A review of biogeochemical controlling processes. Water Res. 2008, 42, 4215-4232. [CrossRef] [PubMed]

74. Manca, F. Nitrate removal and nitrous oxide production of denitrifying woodchip bioreactors under subtropical and tropical climates. Ph.D. Thesis, Queensland University of Technology, Brisbane, QLD, Australia, 2021.

75. Liang, X.; Lin, L.; Ye, Y.; Gu, J.; Wang, Z.; Xu, L.; Jin, Y.; Ru, Q.; Tian, G. Nutrient removal efficiency in a rice-straw denitrifying bioreactor. Bioresour. Technol. 2015, 198, 746-754. [CrossRef] [PubMed]

76. McLaughlan, R.G.; Al-Mashaqbeh, O. Effect of media type and particle size on dissolved organic carbon release from woody filtration media. Bioresour. Technol. 2009, 100, 1020-1023. [CrossRef] [PubMed]

77. Warneke, S.; Schipper, L.A.; Bruesewitz, D.A.; McDonald, I.; Cameron, S. Rates, controls and potential adverse effects of nitrate removal in a denitrification bed. Ecol. Eng. 2011, 37, 511-522. [CrossRef]

78. Xu, Z.; Dai, X.; Chai, X. Effect of influent $\mathrm{pH}$ on biological denitrification using biodegradable PHBV/PLA blends as electron donor. Biochem. Eng. J. 2018, 131, 24-30. [CrossRef]

79. Lepine, C.; Christianson, L.E.; Sharrer, K.; Summerfelt, S. Optimizing hydraulic retention times in denitrifying woodchip bioreactors treating recirculating aquaculture system wastewater. J. Environ. Qual. 2016, 45, 813-821. [CrossRef]

80. Healy, M.G.; Barrett, M.; Lanigan, G.J.; Serrenho, A.J.; Ibrahim, T.G.; Thornton, S.F.; Rolfe, S.A.; Huang, W.E.; Fenton, O. Optimizing nitrate removal and evaluating pollution swapping trade-offs from laboratory denitrification bioreactors. Ecol. Eng. 2015, 74, 290-301. [CrossRef]

81. Lam, P.; Kuypers, M.M.M. Microbial Nitrogen Cycling Processes in Oxygen Minimum Zones. Annu. Rev. Mar. Sci. 2011, 3, 317-345. [CrossRef] [PubMed]

82. Fenton, O.; Healy, M.G.; Brennan, F.P.; Thornton, S.F.; Lanigan, G.J.; Ibrahim, T.G. Holistic evaluation of field-scale denitrifying bioreactors as a basis to improve environmental sustainability. J. Environ. Qual. 2016, 45, 788-795. [CrossRef] [PubMed] 